\title{
Hepatic Copper Metabolism in a Mouse Model for Menkes' Kinky Hair Syndrome
}

\author{
RICARDO O. CASTILLO, M. MICHAEL THALER, CYNTHIA O'TOOLE, AND \\ SEYMOUR PACKMAN \\ Department of Pediatrics Division of Gastroenterology [R.O.C., M.M.T.J and Genetics [C.O., S.P.], and the Liver \\ Center [R.O.C., M.M.T.], University of California, San Francisco, California 94143
}

\begin{abstract}
Menkes' kinky hair syndrome (KHS) is a lethal $x$-linked neurodegenerative disorder of copper metabolism, with low serum copper concentrations, tissuespecific copper sequestration, and decreased activities of cuproenzymes in a number of cell types. Although liver copper accumulation is abnormal in KHS, the actual defect in hepatic copper metabolism has not been elucidated. Our studies of liver copper metabolism were conducted in the mottled (blotchy) mouse, an animal model of KHS. After implantation of central venous and biliary catheters in both blotchy and control mice, we measured biliary copper excretion, hepatic copper uptake, and tissue copper contents over an 8-h period after i.v. bolus administration of radioactive ${ }^{64} \mathrm{Cu}$. Under the experimental conditions used, bile flow and biliary bile acid excretion were held constant, and control and blotchy hepatic ${ }^{64} \mathrm{Cu}$ concentrations were similar in the face of the expected differential in control and mutant kidney ${ }^{64} \mathrm{Cu}$ contents. Biliary excretion of radiocopper was $24.7 \pm 1.5 \%$ of injected ${ }^{64} \mathrm{Cu}$ over $8 \mathrm{~h}$ in control animals, whereas heterozygotes excreted $6.5 \pm$ $1.3 \%$ and a single hemizygote excreted less than $2 \%$. The pattern of biliary copper excretion was different, with sharp increase and steady decline in control biliary ${ }^{64} \mathrm{Cu}$ excretion but consistently low excretion in mutant mice. No differences were observed in control or mutant hepatic uptake of ${ }^{64} \mathrm{Cu}$. These data show a reduced biliary excretion of copper in the blotchy mouse, in the absence of a defect in hepatic copper uptake. We suggest that defective copper transport from hepatocyte to bile represents the hepatic expression of the mottled mutation and speculate that a similar defect occurs in human KHS. These conclusions are consistent with the hypothesis that the basic defect in mottled mutants and in KHS affects cellular copper transport or the intracellular delivery of copper to cellular transport systems. (Pediatr Res 27: 492-496, 1990)
\end{abstract}

Abbreviations

KHS, kinky hair syndrome

Menkes' KHS is a lethal x-linked neurodegenerative disorder of copper metabolism featuring low serum copper levels and decreased activities of cuproenzymes $(1,2)$. The clinical manifestations of KHS were initially attributed to poor copper absorption and resultant copper deficiency in affected tissues (3, 4). Subsequent observations revealed abnormal patterns of cop-

Received March 24, 1989; accepted December 27, 1989.

Correspondence to: Ricardo O. Castillo, M.D., Division of Gastroenterology and Nutrition, Department of Pediatrics, S-322, Stanford University Medical Center, Stanford, CA 94305

Supported by National Institutes of Health Grants HD03148 and GM 28838. per distribution in various organs. Elevations of copper in kidney, intestine, and connective tissue were accompanied by concomitant deficiency in other tissues. Copper deficiency, possible copper toxicity, and defective copper use have been advanced as possible causes of the multisystem lesions observed in patients with KHS (5-8).

Mice mutant at the $x$-linked mottled locus provide an accurate animal model of KHS (8-10). A number of allelic mutations have been described designated as "blotchy," "brindled," and others, based on coat, color, pattern, and other features. The mutant mouse displays defective hair structure, decreased pigmentation, skeletal abnormalities, growth retardation, arterial aneurysms, and characteristics neurologic abnormalities. The concordance of these abnormalities with the characteristic features of KHS strongly suggests that the $x$-linked mutation in mouse and man is homologous, a notion supported by the fact that $\mathrm{x}$-linked loci are highly conserved through evolution (11).

The liver is the major organ of copper metabolism in mammals. At autopsy, newborns and older infants with KHS have markedly reduced hepatic copper levels (7). Kinetic studies with radiocopper in the mottled mouse have shown normal hepatic copper uptake, but defective retention with rapid loss of radiocopper from the liver $(8,13)$. Defective retention of copper in the liver may reflect an alteration in hepatic copper transport or disposition, or excessive avidity of certain extrahepatic tissues for copper. Normal copper incorporation into ceruloplasmin in KHS and the mottled mouse $(14,15)$ suggests that hepatic disposition of copper by that route is unaffected by the KHS mutation.

To further characterize the nature of the hepatic defect in KHS, we studied hepatic disposition of copper in the mottled mouse. The results demonstrate defective biliary copper excretion and hepatic copper retention in the animal model for KHS, supporting the hypothesis that the basic defect in KHS involves disordered copper transport $(21,24,25)$.

\section{MATERIALS AND METHODS}

Animals. Heterozygote females $\left(\mathrm{Mo}^{\text {blo/+ }}\right)$ and normal male mice of strain $\mathrm{C} 57 \mathrm{BL} / 6 \mathrm{~J}$ were purchased as breeding pairs from The Jackson Laboratories, Bar Harbor, ME. The mice were housed in a room set aside for mutant mice in the Animal Care Facility, University of California, San Francisco, where they were provided tap water and Purina Rat Chow (Ralston-Purina, St. Louis, MO) ad libitum. Room lighting was set for $12 \mathrm{~h}$ of daylight by automatic timer. Studies were performed on postweaned adult female heterozygotes, with age- and wt-matched normal homozygous female littermates as controls. A single preweaned male hemizygote $\left(\mathrm{Mo}^{\mathrm{blo} / \mathrm{y}}\right)$ was also available for study, and a preweaned age- and wt-matched male littermate was used as control.

Isotopes. The gamma emitter ${ }^{64} \mathrm{Cu}\left(\mathrm{t}_{1 / 2} 12.8 \mathrm{~h}\right)$ was purchased from New England Nuclear Corporation (Boston, MA) as ${ }^{64} \mathrm{Cu}\left(\mathrm{NO}_{3}\right)_{2}$ and was received at a specific radioactivity of $4 \mathrm{mCi} /$ 

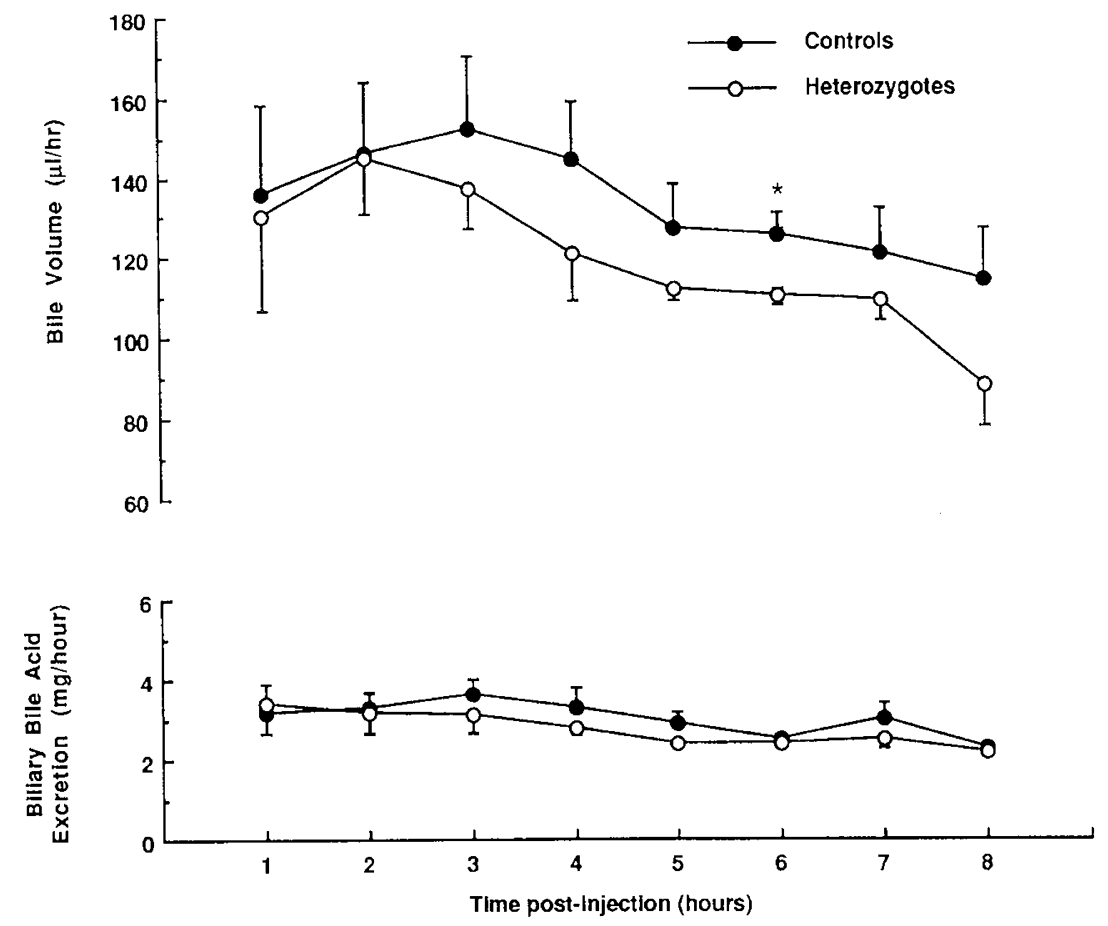

Fig. 1. Bile volume and biliary bile acid content. Five heterozygotic and six control female mice were equipped with central venous infusion catheters and biliary fistulas for collection of bile. The animals were infused with normal saline $(0.3 \mathrm{~mL} / \mathrm{h})$ and sodium taurocholate $(2.0 \mathrm{mg} / \mathrm{h})$. Bile was collected in hourly aliquots, and volume and bile acid content was measured. Data are expressed as mean \pm SEM. "Indicates that the controls and heterozygotes at the indicated time point can be distinguished at $p=0.048$.

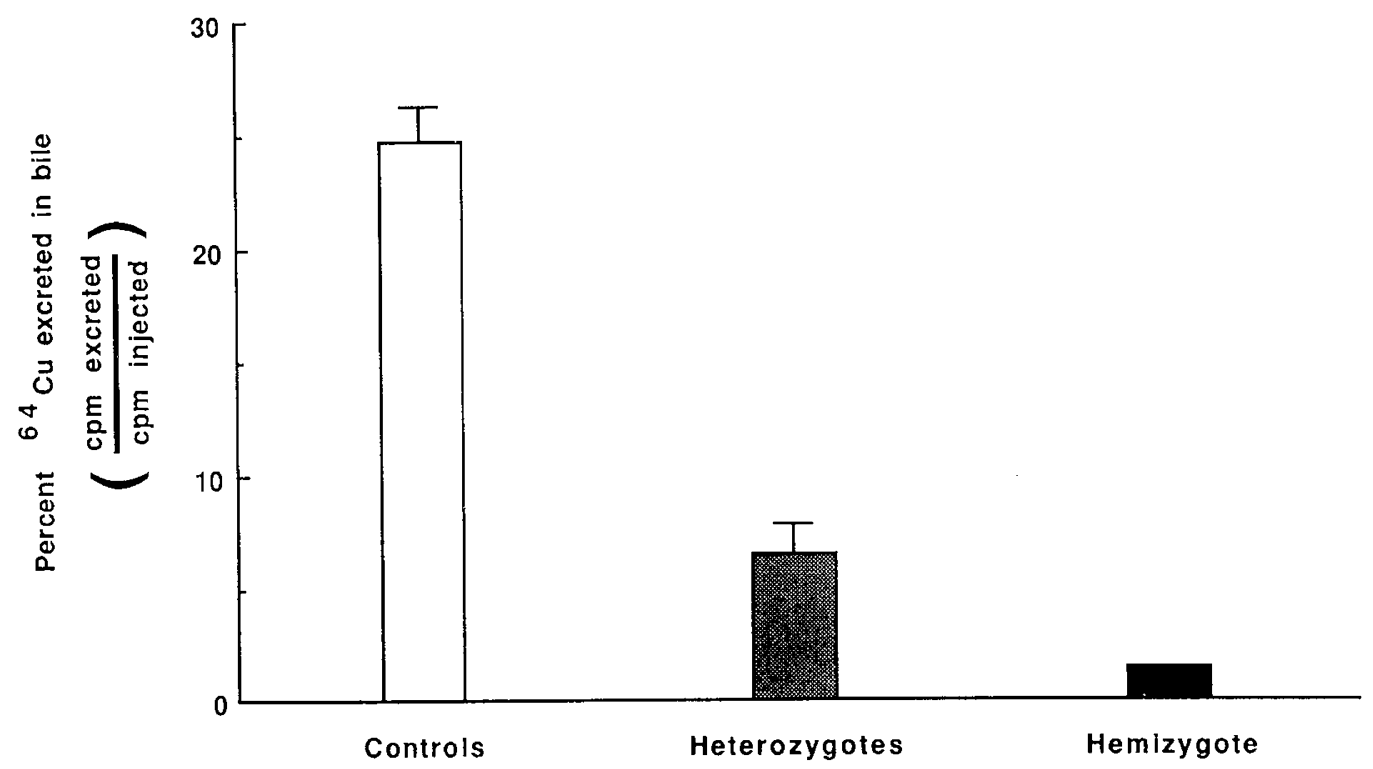

Fig. 2. Total biliary ${ }^{64} \mathrm{Cu}$ excretion. After i.v. injection of ${ }^{64} \mathrm{Cu}(0.5 \mu \mathrm{g} / \mathrm{g})$ to six control mice, five heterozygotes, and a single hemizygote with central infusion catheters and biliary fistulas, bile was collected at 1 -h intervals over $8 \mathrm{~h}$, and excreted ${ }^{64} \mathrm{Cu}$ was measured and totaled for the 8 -h period. The excreted ${ }^{64} \mathrm{Cu} \mathrm{cpm}$ are expressed as the percentage of injected ${ }^{64} \mathrm{Cu} \mathrm{cpm}$, corrected for activity decay, and presented as mean $\pm \mathrm{SEM}$.

$\mathrm{mg}$ of copper. Collected samples were counted directly in a gamma scintillation counter peaked for that isotope. ${ }^{64} \mathrm{Cu}$ counts were corrected for decay (8). Tests of statistical significance were made using the two-tailed $t$ test (27).

Measurement of biliary ${ }^{64} \mathrm{Cu}$ excretion. Central venous catheters were installed in $25-$ to $30-\mathrm{g}$ mice under pentobarbital anesthesia $(50 \mathrm{mg} / \mathrm{kg}$ by intraperitoneal injection). The skin over the right side of the neck was shaved and the right internal jugular vein isolated by blunt dissection through a 1-cm skin incision. After a distal ligature was tied in place, a small incision was made in the vein and a polyethylene catheter (outer diameter 0.037 inches) passed proximally to the superior vena cava. The catheter was sutured in place and connected to a syringe infusion pump.

The gallbladder and porta hepatis were exposed through a midline abdominal incision, and a secure ligature was placed around the common bile duct. A small incision was made in the gallbladder through which a polyethylene catheter (outer diameter 0.024 inches) was placed and securely sutured, with prompt initiation of bile drainage. The abdominal incision was closed, and the mouse placed in a restraint device for the duration of the experiment. Hydration and bile salt concentrations were maintained with continuous i.v. infusion of sodium taurocholate $(2.0 \mathrm{mg} / \mathrm{h})$ in normal saline at a rate of $0.3 \mathrm{~mL} / \mathrm{h}$. The single 


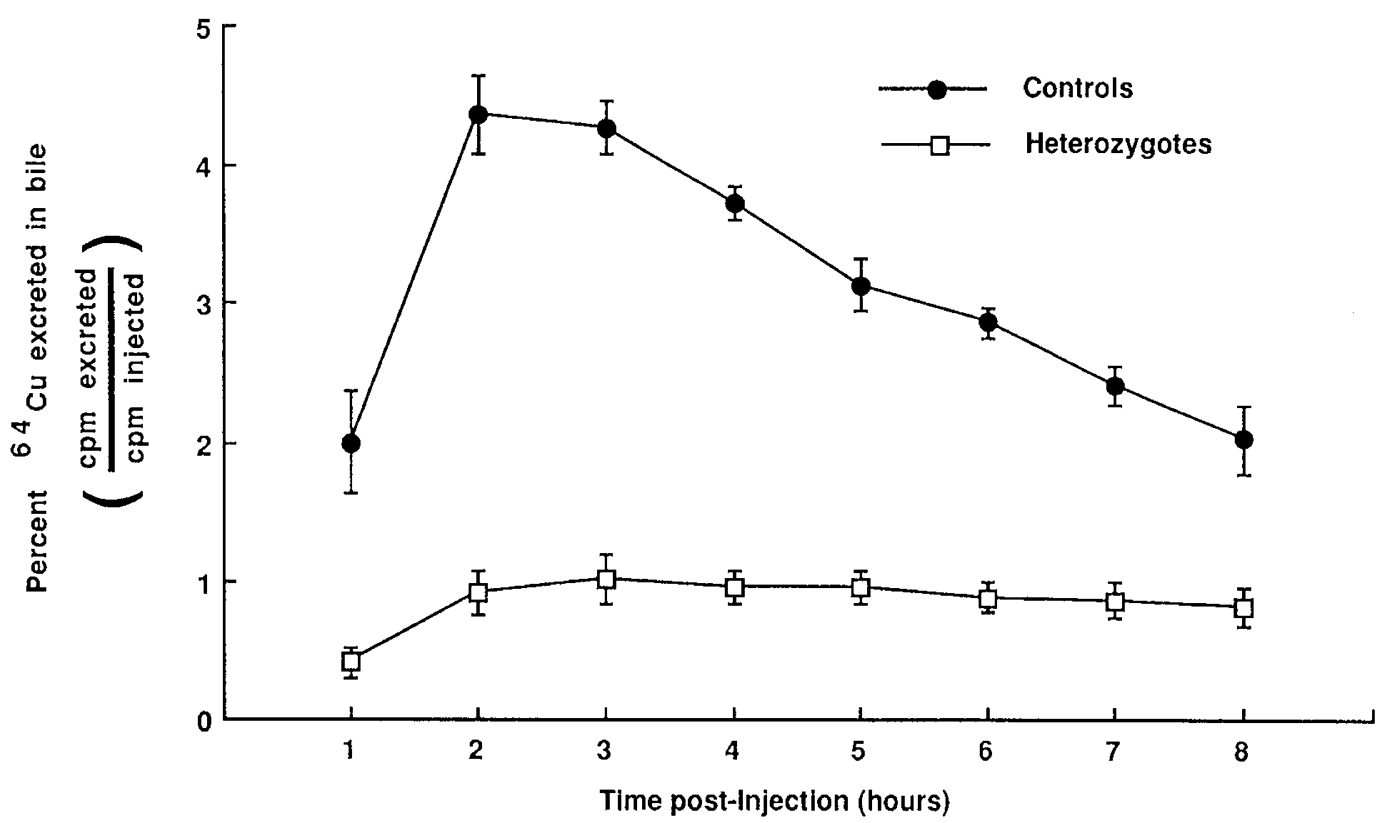

Fig. 3. Biliary ${ }^{64} \mathrm{Cu}$ excretion in normal and mutant heterozygotic mice. Six control and four mutant heterozygote mice were equipped with central venous catheters and biliary drainage catheters. Intravenous infusion with normal saline and sodium taurocholate was initiated and, after a 2-h period of stabilization, ${ }^{64} \mathrm{Cu}(0.5 \mu \mathrm{g} / \mathrm{g})$ was injected i.v. Bile was collected at 1 -h intervals and excreted radioactivity was measured. The excreted ${ }^{64} \mathrm{Cu} \mathrm{cpm}$ are expressed as the percentage of injected ${ }^{64} \mathrm{Cu} \mathrm{cpm}$, corrected for activity decay, and presented as mean \pm SEM.

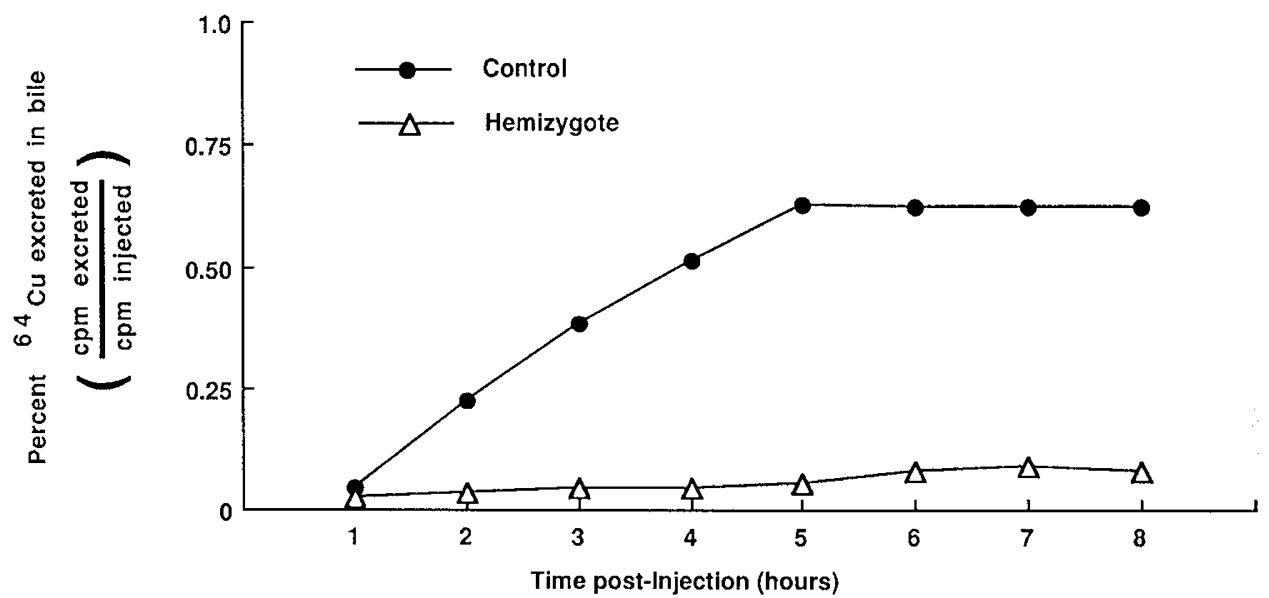

Fig. 4. Biliary ${ }^{64} \mathrm{Cu}$ excretion in a single normal and hemizygotic male mouse. The control and mutant male were equipped with central venous catheters and biliary fistulas. After overnight stabilization with normal saline infusion, ${ }^{64} \mathrm{Cu}(0.5 \mu \mathrm{g} / \mathrm{g})$ was administered by i.v. injection. Bile was collected with $8 \mathrm{~h}$ postinjection and excreted radioactivity was measured. The excreted ${ }^{64} \mathrm{Cu} \mathrm{cpm}$, corrected for activity decay, are expressed as the percentage of injected ${ }^{64} \mathrm{Cu} \mathrm{cpm}$.

male hemizygote and male control did not receive taurocholate infusions.

${ }^{64} \mathrm{Cu}(50 \mu \mathrm{g} / 100 \mathrm{~g}$ body wt) was administered by i.v. pulse injection $1 \mathrm{~h}$ after cannulation and initiation of bile salt infusion. Bile was collected at $1-\mathrm{h}$ intervals for $8 \mathrm{~h}$ after the i.v. radiocopper injection. Total biliary bile acids were measured fluorometrically. using the Sterognost-3 enzymatic method (Nyegaard \& Co., Diagnostics Division, Oslo, Norway) (16). ${ }^{64} \mathrm{Cu}$ excreted in bile was determined by scintillation counting and expressed as percent of injected cpm (mean \pm SEM).

Measurement of tissue ${ }^{64} \mathrm{Cu}$ content. Mice were killed by cervical dislocation $8 \mathrm{~h}$ after ${ }^{64} \mathrm{Cu}$ injection. Samples of liver, kidney, and heart were excised, thoroughly washed in normal saline, and prepared for scintillation counting. Results are expressed as percent of injected counts/g of tissue (mean \pm SEM).

Measurement of hepatic ${ }^{64} \mathrm{Cu}$ uptake. Mice were equipped with central venous catheters only. After i.v. injection of ${ }^{64} \mathrm{Cu}(50 \mu \mathrm{g} /$ $100 \mathrm{~g}$ body wt), serial liver biopsies were obtained from each mouse at 5,10,15, and 30 min postinjection. Biopsy specimens were weighed, washed thoroughly, and prepared for scintillation counting. The percent of injected counts/g of liver tissue was determined and regression lines developed for uptake of isotope by mutant and control liver.

\section{RESULTS}

Bile flow and biliary bile acid excretion data are shown in Figure 1. As can be seen, hourly output of bile (bile flow) did not differ between the heterozygote and control animals with the exception of h $6(p=0.048)$. The total amount of bile excreted over the 8-h course of the experiment also did not differ between the two groups of animals: $1064.5 \pm 96.4 \mu \mathrm{L}$ (controls) versus $968.3 \pm 62.4 \mu \mathrm{L}$ (heterozygotes), $p>0.05$. At no time point did biliary bile acid excretion differ between the two groups.

The cumulative biliary excretion of ${ }^{64} \mathrm{Cu}$ was strikingly lower in mutant mice compared with controls: control females excreted $24.7 \pm 1.5 \%$ whereas heterozygotic mutants excreted $6.5 \pm 1.3 \%$ 


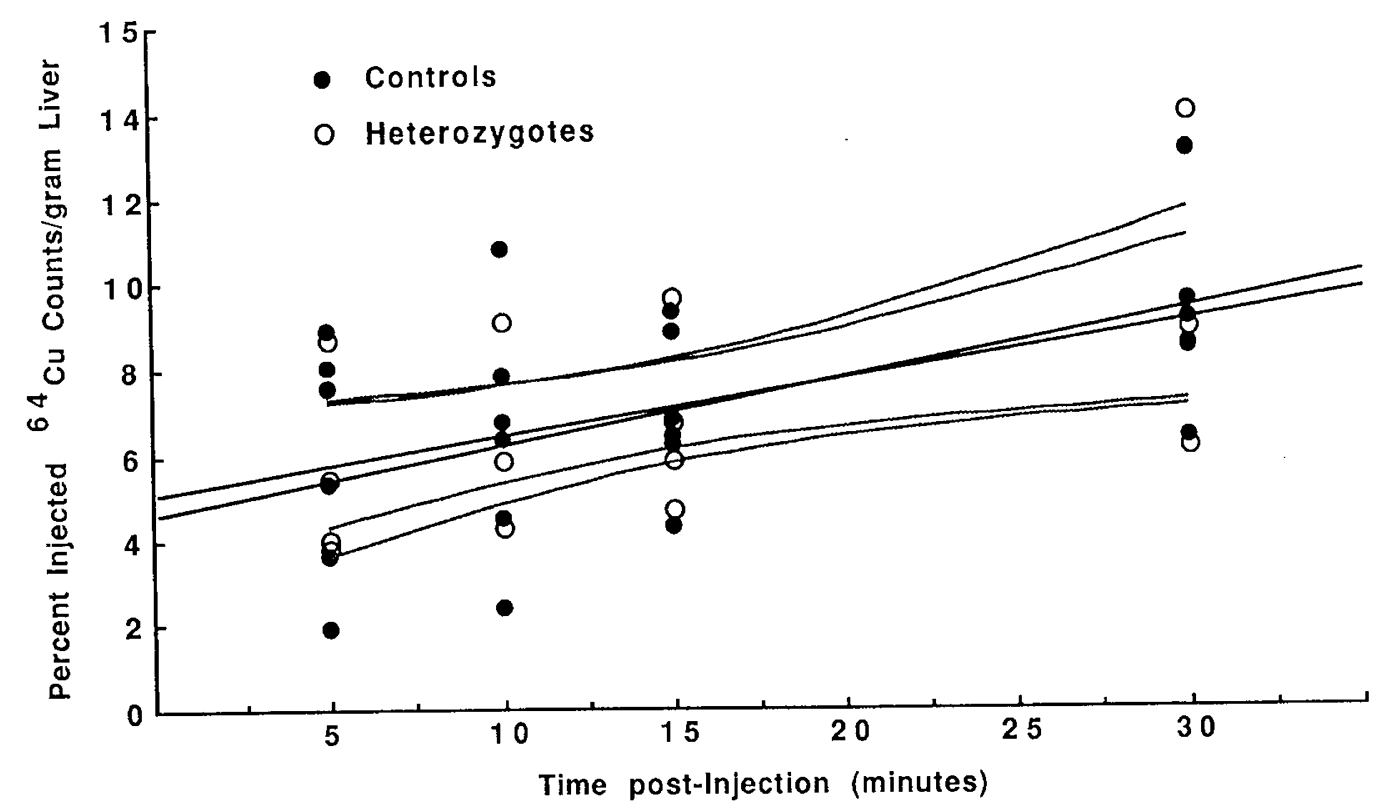

Fig. 5. Hepatic copper uptake. After cannulation with central venous catheters, four heterozygotes and six female control mice were injected i.v. with ${ }^{64} \mathrm{Cu}(0.5 \mu \mathrm{g} / \mathrm{g})$. Serial liver biopsies were obtained from each individual mouse at $5,10,15$, and 30 min postinjection. The percent of injected ${ }^{64} \mathrm{Cu}$ measured in each liver biopsy specimen/g wet wt of liver was determined and regression lines and the $95 \%$ confidence limits calculated. The slopes of the two regression lines are not distinguishable, $p>0.50$.

Table 1. Tissue ${ }^{64} \mathrm{Cu}$ distribution 8 h postinjection of ${ }^{64} \mathrm{Cu}$ (\% injected counts/g tissue, mean \pm SEM)

\begin{tabular}{lcccc}
\hline & $n$ & Liver & \multicolumn{1}{c}{ Kidney } & Heart \\
\hline Control & 6 & $30.3 \pm 8.2$ & $2.8 \pm 0.5$ & $1.5 \pm 0.2$ \\
Heterozygote & 4 & $32.6 \pm 3.2$ & $11.8 \pm 0.6$ & $2.2 \pm 0.4$ \\
& & NS & $p<0.001$ & NS \\
\hline
\end{tabular}

of the injected dose during the study period (Fig. 2). The single hemizygote excreted less than $2 \%$ of injected ${ }^{64} \mathrm{Cu}$. The pattern of biliary copper excretion differed in control and mutant mice. In controls, biliary excretion of ${ }^{64} \mathrm{Cu}$ increased sharply $1-2 \mathrm{~h}$ after injection, declined steadily thereafter, and returned to initial values by the 8th h (Fig. 3). Excretion in heterozygotes remained less than $1 \%$ of the injected dose with a minimal decline during the entire 8 -h collection period. The control-paired hemizygote exhibited little copper excretion (Fig. 4).

As a measure of copper uptake by liver, accumulation of ${ }^{64} \mathrm{Cu}$ was measured at a series of time points postadministration of the radioactive metal in heterozygote and normal control female mice (Fig. 5). The slopes of the regression lines for normal and mutant data points were not different when analyzed by twotailed $t$ test $(p>0.50)$. These data indicate that no differences were found in copper uptake in mutant versus control liver under the experimental conditions used in this study.

Determinations of ${ }^{64} \mathrm{Cu}$ accumulation in liver, cardiac muscle, and kidney were made $8 \mathrm{~h}$ after injection of ${ }^{64} \mathrm{Cu}$ and expressed per g organ wet wt. As shown in Table 1, liver of heterozygote and control animals contained comparable amounts of copper, amounting to $\sim 30 \%$ of the injected $\mathrm{cpm} / \mathrm{g}$ organ wt. Concentrations in cardiac muscle were also similar in heterozygote and control mice, albeit much lower than in liver, amounting to 1.5$2.2 \%$ of injected counts/g tissue. In contrast, radiocopper accumulated in kidney in heterozygous mice was four to five times that recorded in control kidney after $8 \mathrm{~h}$.

\section{DISCUSSION}

Reduced liver copper content has been documented in human KHS (14) and in the mottled mouse $(8,13,15)$, suggesting that altered hepatic copper metabolism is a feature of Menkes' syn- drome. However, the nature of these alterations in the processing of copper by KHS liver is not yet well characterized. Early studies of the response to copper administration in KHS led investigators to postulate a defect in hepatic copper uptake because the liver was observed not to accumulate the exogenous copper although ceruloplasmin responses were normal $(14,15,17,18)$. In these investigations, hepatic copper content was not measured before $24 \mathrm{~h}$ after copper administration, so that early hepatic copper fluxes were not determined. In studies by Mann et al. (12) and Packman et al. (8), distribution of ${ }^{64} \mathrm{Cu}$ in various organs in the mottled mouse was measured. Both investigators observed comparable hepatic ${ }^{64} \mathrm{Cu}$ uptake in normal and mutant mice and rapid loss of the radiocopper so that by $24 \mathrm{~h}$ postinjection, mutant hepatic ${ }^{64} \mathrm{Cu}$ levels were lower than control levels. These studies suggested a normal hepatic copper uptake, but abnormal copper retention in the mottled mouse. In studies by Mann et al. (12), reductions in biliary copper concentrations were noted in brindled mutant mice.

We investigated biliary copper excretion and hepatic copper uptake using ${ }^{64} \mathrm{Cu}$ in the mottled $\left(\mathrm{Mo}^{\text {blo }}\right)$ mouse. Our results show a striking reduction in the biliary excretion of radiocopper by the mutant mouse under controlled experimental conditions. The i.v. infusion of fluids and sodium taurocholate, the major bile salt found in mice, maintained bile flow and biliary bile acid concentration at physiologic levels in both mutant and control animals throughout the course of the experiment. Radiocopper was i.v. pulse-injected, ensuring uniform systemic delivery of the ${ }^{64} \mathrm{Cu}$. It is unlikely that the differences in biliary copper excretion can be explained by differential hepatic copper levels because the control and mutant animals were matched for age and wt, and no difference in hepatic ${ }^{64} \mathrm{Cu}$ content was noted $8 \mathrm{~h}$ after radiocopper administration. These results imply the presence of a biliary copper excretory defect in the mottled mouse, and, by analogy, in human KHS. If such a defect does, in fact, exist in human KHS, then a mechanism is suggested to explain the prolonged radiocopper biologic half-lives described in KHS patients by Dekaban et al. (19). Although the pattern of biliary copper excretion in the control male (Fig. 4) differed from that of control females (Fig. 4), most likely reflecting possible sex differences and lack of taurocholate infusions, the fully affected 
hemizygote clearly excreted far less copper in bile compared with his male counterpart.

Our data on the hepatic uptake of ${ }^{64} \mathrm{Cu}$ confirm previous findings in liver $(8,13,15)$ and in fibroblasts $(26)$. On direct evaluation of liver radiocopper content by serial liver biopsy, no difference was found between mutant and control animals. These data demonstrate that within the limits of the experimental methods used in this study, the mutant liver demonstrated no defect in copper uptake.

If our analogy is correct, and there is defective hepatic copper excretion in KHS, then the characteristically low liver copper levels in KHS must be explained. The pathogenesis of the low hepatic copper levels in KHS may be related to dynamic factors affecting total body metabolism of copper: decreased delivery of copper to liver and other organs due to the intestinal block in copper absorption; excessive avidity of extrahepatic tissues for copper; and continued copper loss as ceruloplasmin, with the liver being the only organ able to so export the metal into the circulation. The above combination would result in a strong tendency toward hepatic copper depletion in KHS.

Because of normal hepatic ceruloplasmin metabolism and characteristic low hepatic copper content found in KHS, it has been unclear whether the liver is a tissue that expressed the mutation. In one study, abnormal subcellular distribution of copper suggested expression of the defect in liver even in the absence of excessive copper sequestration (8). Our results suggest that impaired biliary copper excretion represents expression of the mutation by the liver, implying that the $\mathrm{x}$-linked function expressed as a defect in mutant copper transport plays an essential role in transfer of copper from the hepatocyte to bile.

It is of interest that the two inborn errors of copper metabolism, Wilson disease and KHS, are distinct in phenotype, yet share a defect in biliary copper excretion. In Wilson disease, diminished biliary excretion of copper is a reproducible abnormality in hepatic copper metabolism (23), suggesting that this autosomal recessive gene product plays a vital role in copper excretion in bile. Because the KHS mutation involves a different chromosomal locus, these two genetic diseases may affect different steps in the process of biliary copper excretion. A more complete understanding of these mutants should therefore provide insights into the biochemistry and cell biology of hepatic copper disposition.

The basic defect in KHS remains unknown, but the manifestations of the syndrome are thought to involve low cuproenzyme activity in tissues with deficient copper content and defective copper use in tissues expressing the mutant phenotype of copper sequestration (5-7). Whereas concentrations of metallothionein, a major intracellular copper-binding protein, are increased in KHS cells expressing the copper sequestration phenotype, the regulation of copper-binding metallothionein is normal in KHS. Increases in intracellular metallothionein concentrations are most likely secondary to intracellular copper sequestration due to some other primary cause (24-26). Our observations on biliary transport of copper are consistent with the previously formulated hypothesis $(21,22,24,25)$ that the primary cause is a defect in cellular copper transport or intracellular translocation of copper to copper-specific transport systems.

\section{REFERENCES}

1. Menkes JH, Alter M, Steigleder GK, Weakley DR, Sung JH 1962 A sex-linked recessive disorder with retardation of growth, peculiar hair, and facial cerebral and cerebellar degeneration. Pediatrics 29:764-779

2. Holtzman NA 1976 Menkes' Kinky Hair Syndrome: a genetic disease involving copper. Fed Proc 35:2276-2280

3. Danks DM, Campbell P, Walker-Smith J, Stevens BJ, Billespied JM, Blomfield J 1972 Menkes' Kinky Hair Syndrome. Lancet 1:1 100-1102

4. Danks DM, Campbell P, Stevens B, Wayne V, Cartwright E 1972 Menkes' Kinky Hair Syndrome: an inherited defect in copper absorption with widespread effects. Pediatrics 50:188-201

5. Danks E, Cartwright E, Stevens B, Townley R 1973 Menkes' Kinky Hair Disease: further definition of the defect in copper transport. Science 179:1140-1142

6. Garnica AD, Fletcher SR 1975 Parenteral copper in Menkes' Kinky Hair Syndrome. Lancet 2:659-660

7. Horn N, Mikelsen M, Haydorn K, Damsgaard E, Tygstrus I 1975 Copper and steely hair. Lancet 1:1236

8. Packman S, O'Toole C, Price D, Thaler MM 1983 Cadmium, zinc and copper metabolism in the mottled mouse, an animal model for Menkes' Kinky Hair Syndrome. J Inorg Biochem 19:203-211

9. Hunt DM 1974 Primary defect in copper transport underlies mottled mutants in the mouse. Nature 249:852-854

10. Danks DM 1975 Steely hair, mottled mice and copper metabolism. N Engl J Med 293:1147-1149

11. Ohno S 1974 Conservation of ancient linkage groups in evolution and some insight into the genetic regulatory mechanism of X-inactivation. Cold Spring Harbor Symp. Quant Biol 38:155-164

12. Mann JR, Camakaris J, Danks DM 1979 Copper metabolism in mottled mouse mutants: distribution of ${ }^{64} \mathrm{Cu}$ in brindled $\left(\mathrm{Mo}^{\mathrm{br}}\right)$ mice. Biochem $\mathrm{J}$ 180:613-619

13. Camakaris J, Mann JR, Danks DM 1977 Copper metabolism in mottled mouse mutants: copper concentrations in tissues during development. Biochem J 180:597-604

14. Nooyen JL, DeGroot CJ, Van den Hamer CJA, Monnens LAH, Willemse J Niermeijer MF 1981 Trace element studies in three patients and a fetus with Menkes' disease. Effect of copper therapy. Pediatr Res 15:284-289

15. Mann JR, Camakaris J, Dankes DM, Williczek EG 1979 Copper metabolism in mottled mouse mutants: Copper therapy of brindled $\left(\mathrm{Mo}^{\mathrm{br}}\right)$ mice. Biochem J 180:605-612

16. Osuga T, Miamura K, Nushiya F, Iwai K 1977 Evaluation of fluorometrically estimated serum bile acid in liver disease. Clin Chim Acta 75:81-90

17. Van den Hamer CJA, Prins HW $1978 \mathrm{Cu}$-content of the liver of young mice in relation to a defect in the Cu-metabolism. In: Kirchgessner M (ed) Trace Element Metabolism in Man and Animals, Vol 3. Arbeitskreis für Tierennährungforschung, Weihenstephen, FRG, pp 397-400

18. Evans GW, Reis BL 1978 Impaired copper homeostasis in neonatal male and adult female brindled $\left(\mathrm{Mo}^{\mathrm{br}}\right)$ mice. J Nutr 108:554-560

19. Dekaban AS, Aamodt R, Rumble WF, Johnston GF, O'Reilly S 1975 Kinky hair disease: study of copper metabolism with use of ${ }^{64} \mathrm{Cu}$. Arch Neurol 32:672-675

20. Owen CA, Orvis AL 1970 Release of copper by rat liver. Am J Physiol 218(1):88-91

21. Packman S, Chin P, O'Toole C 1984 Copper utilization in cultural skin fibroblasts of the mottled mouse, an animal model for Menkes' Kinky Hair Syndrome. J Inherited Metab Dis 7:168-170

22. Danks DM, Camakaris J, Stevens BJ 1978 The cellular defect in Menkes' syndrome and in mottled mouse. In: Kirschgessner M (ed) Trace Element Metabolism in Man and Animals, Vol 3. Arbeitskreis für Tierennährungforschung, Weihenstephen, FRG, pp 401-404

23. Strickland GT, Beckner WM, Leu M-L, O'Reilly S 1972 Turnover studies of copper in homozygote and heterozygote for Wilson's disease and controls: isotope tracer studies with ${ }^{64} \mathrm{Cu}$. Clin Sci 43:605-615

24. Packman S, Palmiter R, Karin M, O'Toole C 1987 Metallothionein messenger RNA regulation in the mottled mouse and Menkes' kinky hair syndrome. $J$ Clin Invest 79:1338-1342

25. Packman S 1987 Regulation of copper metabolism in the mottled mouse. Arch Dermatol 123:1545-1547a

26. Packman S, O'Toole C 1984 Trace metal metabolism in cultured skin fibroblasts of the mottled mouse; response to metallothionein in inducers. Pediatr Res 18:1282-1286

27. Glantz SA 1987 Correlation and correlation coefficients. In: Primer of Biostatistics. 2nd ed, McGraw-Hill Inc., New York, pp 210-221 